\title{
Classification of Wadi system based on floristic composition and edaphic conditions in South Sinai, Egypt
}

\author{
Abdelraouf A. Moustafa ${ }^{1}$, Ashraf A. Salman', Ahmed E. Elrayes ${ }^{3}$, and Michael Bredemeire ${ }^{4}$ \\ ${ }^{1}$ Botany Department, Faculty of Science, Suez Canal University, Egypt. \\ ${ }^{2}$ Botany Department, Faculty of science, Port said University, Egypt. \\ ${ }^{3}$ Geology Department, Faculty of Science, Suez Canal University, Egypt. \\ ${ }^{4}$ Forest Ecosystems Research Center, Goettingen University, Germany.
}

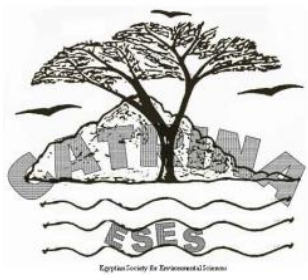

\begin{abstract}
The present work aims to study the vegetation distribution and floristic composition according to the wadi system classification in Saint Cathrine Protectorate. The climate of the study area is extremely arid, with a long hot and rainless summer and mild winter. During the study, vegetation survey for the main wadis in southern Sinai was conducted, representing ecological variations such as elevation, physiographic characters, and soil conditions. Quantitative study of 317 stands in twenty-two wadis in southern Sinai, was done including; vegetation parameters such as total plant cover, physical and chemical soil analysis of the selected wadis. Temperature and moisture were the main factors controlling the floristic and structural distribution of vegetation in the study area. Species richness and diversity was highest in subsub basins and lowest in basins. Vegetation analysis in all wadis were classified into four groups; group (A) main-basin area included, Zilla spinose, Artemisia judaica, Hamada elegans and Anobasis articulata in five assemblages, group (B) basin area included Artemisia judaica, group (C) sub-basin area included Alkanna orientalis and Artemisia judaica, finally group (D) sub-sub-basin area included Artemisia inculta, Alkanna orientalis and Artemisia judaica. In conclusion, different wadi ranks had unique environmental conditions which controlled types and distribution of vegetation.
\end{abstract}

Keywords: Phytogeography, physiography, TWINSPAN, Wadi system, Saint Cathrine.

\section{INTRODUCTION}

South Sinai is an ecologically interesting region because of its physiographic variations and environmental gradients. Its vegetation characterized by the dominance of four large families: Compositae, Leguminosae, Labiatae and Zygophyllaceae. In general, the vegetation of south Sinai is very restricted to many land forms, Moustafa and Klopatek (1995) described the vegetation of the Saint Catherine area considering six distinguished landforms: gorges, slopes, terraces, ridges, wadis, and plains.

Boulos, (1982) estimated that Sinai contains about 1000 species of higher plants representing $40 \%$ of the Egyptian flora. The unique geographical position of Sinai, linking Asia and Africa and not very far from Europe is reflected in its unique flora. This geographic position explains the presence of species characteristics of the Mediterranean littoral, as well as those of the high mountain chains extending to Iran in the east and to the African subtropics in the south. With these different origins and the diversity of the Sinai habitats, Boulos, (1982) distinguished the vegetation of the Sinai Peninsula into eight types: Remnants of the coniferous forests, dwarf mountain vegetation including about thirty endemic species, Mediterranean semi-arid vegetation, arid vegetation, vegetation of coastal sand dunes and saline marches, hot desert vegetation's near the southern coasts, spammed arid area and Mangrove vegetation at coastal areas of the Red Sea.

Moustafa and Zaghloul (1996) studied the complex interrelations between elevation, edaphic features, topography, and prevailing wind speed and vegetation distribution on the Saint Catherine Mountains. The high mountains support mainly Irano-Turanian steppe vegetation dominated by Artemisia herba-alba L. accompanied by Gymnocarpos decander Forssk. Lower elevations are dominated by Artemisia herba-alba L. with Zilla spinosa L. and Fagonia mollis Delile. On stony alluvium of ridges, Agathophora alopecur-oides L. and Atraphaxis spinosa L. on soils derived from dark volcanic rocks (Saint Catherine mountain), and Stachys aegyptiaca L. and Tanacetum santolinoides Nevski on terraces. Characteristic trees and shrubs include: Crataegus sinaica L., Ficus palmate L., Cotoneaaster orbicularis Medic. Sageretia thea Brongn and Rhus tripartite L. (Moustafa, 1990).

The present work aims to study the classification of vegetation data to figure out the floristic composition of different wadi groups in south Sinai and its relation to soil variations and environmental factors in each community.

\section{Study area}

\section{Location and Geography}

The location of the study area concerted on the southern part of Sinai. The study area is located between $33^{\circ} 32^{\prime}$ to $34^{\circ} 00^{\circ}$ east and $28^{\circ} 30^{\prime}$ to $28^{\circ} 46^{\prime}$ north. It occupies an area approximately $2500 \mathrm{~km}^{2}$. The area has a length of about $140 \mathrm{~km}$ extending from the Gulf of Suez to Saint Catherine national park and the main town of Saint Catherine with the world-famous $6^{\text {th }}$ century monastery of Saint Catherine (Figure 1).

The study area is characterized by a complicated system of deep wadis, some of which reach a cons-iderable length (e.g., wadi El-Sheikh) and some are shorter, 
narrower and steeper, and represent tributaries of the main wadis (e.g., wadi El-Arbain) (Figure 2).

\section{Geology and Geomorphology}

In general, Hammad (1980) divided Sinai into seven main geomorphologic districts; the southern elevated mountainous part, the central plateau, the hilly area, the north and north-made coastal plain, the marshy and sabakhas, the alluvium coastal plains, and the lakes.

Sinai Peninsula is conventionally and administeratively divided into northern and southern territories. Zohary (1973) and Said (1990) summarized the geomorphology as a plateau tilting upward towards the south Sinai. The southern part of the peninsula which is bounded to the west and the east by Suez and Aqaba Gulf, respectively, is generally composed of a broad belt of dark-colored purplish or reddish sandstones. To the south, there is a triangular mass of mountains with its apex at Ras Mohammed to the south, $7500 \mathrm{~km}^{2}$ in surface area, formed of igneous and metamorphic rocks, chiefly granites. This mass of mountains is intensively rugged and dissected by a complicated system of deep wadis, some of which reach a considerable length (e.g. wadi Feiran and wadi Gharandal) and some are shorter, narrow and steeper, and represent tributaries of the main wadis (e.g. wadi El-Arbain, wadi El-Sheikh and wadi Sa'al) (Shabana,1988). Progressing inland, the wadis become deeper and the igneous hills become higher.

In this triangular southern mass, the igneous complex has been relieved of its sandstone over-burden and so manifests the characteristics of a true mountain range. This range is divided into three clusters of peaks: Mount Serbal in west (2070 m a.s.l.). Mount Mousa (2285 m a.s.1.) and Gebal Catherine (2641 $\mathrm{m}$ a.s.1.) group in the center and Gebal Um-Shomer (2586 $\mathrm{m}$ a.s.1.) in the south. Gebel Catherine represents a series of mountains at different elevations with four large valleys (wadi ElSbaiya, wadi El-Ruting, wadi El-Arbain, wadi Zawateen, and wadi Razana) (Said, 1990; Moustafa, 1990). The valleys are long, winding with a serpentine course, and contain many water springs and wells that support a unique agriculture consisting of small gardens and palms (Figures 1\& 2).

Kassem (1981) discussed that the floor of the wadis are covered by alluvial and colluvial deposits which are the result of disintegration processes of the surrounding mountain rocks. Thus, they have the same composition as the parent rocks and range in grain size between boulders with diameter more than $10 \mathrm{~m}$ to very fine elastic or clay size particles.

The soil of wadi Ghreaba, the beds of the runnels are of bare rock, filled by falls and cataracts. The main drainage channels are rich in fill deposits. Some of the main wadis and their tributaries are filled with alluvial and lacustrine deposits of 4-12 m depth (Kassem, 1981). They form considerable reservoirs for ground water. The soil mainly consists of loose pebbles, gravels and sometimes cobbles embedded in sandy matrix. The bed rocks in wadi El-Sheikh are mostly granitic, in wadi Solaf, and wadi El-Akhdar (Kassem, 1981).

Said (1962) described the geologic area as predomin- antly smooth-faced granite outcrops forming mountains such as Gebel Serbal, Ras Safsafa and Gebel El-Rabah. Black mountains consisting of old volcanic rocks are rather common. These mountains were uplifted to their present altitude through stages starting at the end of the Miocene.

Said (1990) described the geomorphology of the Saint Catherine area to forms a part of the highly rugged mountains with acid plutonic and volcanic rocks belonging to the Precambrian basement complex of the southern part of Sinai Peninsula, which is dissected by numerous incised wadis that are everywhere showing signs of down cutting.

\section{Wadi El-Arbain}

Wadi El-Arbain is deep, narrow and roughly filled by huge boulders. The bed rocks in wadi El-Arbain are mostly granitic, the main wadi-bed and its tributaries are filled with alluvial. The height above sea level of the site of the stand studies ranges from 1580 to $1660 \mathrm{~m}$ that stand studies are location on land form (wadi-bed, slope and terraces) in wadi El-Arbain. Wadi El-Arbain is start from the village of Saint Catherine to the Bedouins home (Ramadan home), it is contain in this area along three gardens. The width of wadi El-Arbain along this area varies from 30 to $50 \mathrm{~m}$.

Wadi El-Arbain has a reasonable supply of fresh water, with the main water well, Bir El-Arbain in wadi El-Arbain itself on the middle along on this area. The location of Bir El-Arbain is beside on small Church and Mousa stone. Bir El-Arbain considers main source of water on human and supports of all gardens. Wadi ElArbain area is drained by a number of principal wadis and their tributaries.

\section{Shaq-Mousa}

Sub sub-basin area is bounded approximately by latitudes $28^{\circ} 52^{\prime}$ to $28^{\circ} 53^{\prime}$ north and longitudes $33^{\circ} 56^{\circ}$ to $33^{\circ} 57^{`}$ east. Shaq-Mousa area is rock unit volcanic; it is very narrow and roughly filled by huge boulder. The height above sea level of location stand studies ranges from 1690 to $1760 \mathrm{~m}$, the width of this wadi along area varies from 6 to $50 \mathrm{~m}$.

\section{Hamata}

Sub sub-basin area is bounded approximately by latitudes $28^{\circ} 52^{`}$ to $28^{\circ} 53^{`}$ north and longitudes $33^{\circ} 56^{`}$ to $33^{\circ} 57^{\circ}$ east. It is consists of the rock granites and alluvial, the width of this wadi along area varies from 25 to $30 \mathrm{~m}$. The height above sea level of location stand studies ranges from 1610 to $1760 \mathrm{~m}$.

\section{Gragnia}

Sub sub-basin area is bounded approximately by latitudes $28^{\circ} 52^{\prime}$ to $28^{\circ} 53^{\prime}$ north and longitudes $33^{\circ} 56^{\prime}$ to $33^{\circ} 57^{\circ}$ east. Gragnia area consists of volcanic and alluvial rocks. It is very narrow and roughly filled by huge boulder; the width of this wadi along area varies from 5 to $20 \mathrm{~m}$ and become about $2 \mathrm{~m}$ at the end. The height above sea level of location stand studies ranges from 1620 to $1780 \mathrm{~m}$.

Shaq-Mousa area, Hamata area and Gragnia area is meeting together in one mouth, which it is area consider 
collection of water coming from all mountains surrounding, water collection directed into wadi El-Arbain. The width of mouth area is about 35 to $40 \mathrm{~m}$. The total area of wadi El-Arbain, Shaq-Mousa area, Hamata area and Gragnia area is about $12.5 \mathrm{~km}^{2}$.

\section{Wadi El-Faraa}

Sub-basin area is bound approximately by latitudes $28^{\circ} 54^{\prime}$ to $28^{\circ} 55^{\prime}$ north and longitudes $33^{\circ} 51^{\prime}$ to $33^{\circ}$ $52^{\prime}$ east. Wadi El-Faraa area consists of granite and alluvial rocks. Two road to inter of this area; one direct from wadi El-Arbain and another direct from the village of Saint Catherine, it is consider parallel on wadi ElArbain.

Wadi El-Faraa area consists of two main parts, first part characterized by its high elevation with width about 60 to $70 \mathrm{~m}$ and the second part is deep, narrow about 15 to $20 \mathrm{~m}$, on the anther hand roughly filled by huge boulders. Wadi El-Faraa forms an area of about 2.13 $\mathrm{km}^{2}$, it is surrounding by mountains on both sides. The height above sea level ranges from 1720 to $1520 \mathrm{~m}$ a.s.1.

\section{Wadi El-Dair}

Sub-basin area is considering one of the important parts on southern Sinai, Egypt to visit of Tourism from all worlds. It is containing Saint Catherine Monastery. It is bound approximately by latitudes $28^{\circ} 54^{\prime}$ to $28^{\circ} 56^{\circ}$ north and longitudes $33^{\circ} 55^{\circ}$ to $33^{\circ} 56^{\circ}$ east. Wadi ElDair area is consists of volcanic and granite rocks. It is deep, narrow and roughly filled by huge boulders. The bed rocks in wadi El-Dair is mostly granitic, the main wadibed and their tributaries are filled with alluvial.

Wadi El-Dair forms an area of about $5.25 \mathrm{~km}^{2}$. The height above sea level of site of the stand studies ranges from 1580 to $1660 \mathrm{~m}$, that stand studies are location on land form (wadi-bed, slope and terraces) in wadi ElDair,. It is characterized by its general gentle slope; the width of this wadi along area varies from 20 to $30 \mathrm{~m}$. The main peaks in the area are Gebel Moneiga (1954 m a.s.1.), Gebel Ahmar (2318 m a.s.1.), Gebel Mousa (2245 $m$ a.s.1.) and Gebel El-Dair (2065 m a.s.1.).

\section{El-Raha plain}

It is characterized by sandy and widely area. El-Raha plain area is bound approximately by latitudes $28^{\circ} 56^{\circ}$ to $28^{\circ} 57^{`}$ north and longitudes $33^{\circ} 51^{\prime}$ to $33^{\circ} 53^{`}$ east. El-Raha plain forms an area of about $1 \mathrm{~km}^{2}$. It is rock unite mostly granite. It is contain El-Raha Hotel, Bedouins of village and new governmental balding.

Wadi El-Raha has a reasonable supply of fresh water, with the main water well, Bir El-Raha in wadi El-Raha itself. The height above sea level of site of the stand studies ranges from 1580 to $1400 \mathrm{~m}$. The diameter of this area is about $300 \mathrm{~m}$.

\section{Wadi El-Toffaha}

It is bound approximately by latitudes $28^{\circ} 55^{\prime}$ to $28^{\circ} 56^{`}$ north and longitudes $33^{\circ} 53^{\prime}$ to $33^{\circ} 54^{`}$ east. Wadi El-Toffaha forms an area of about $2.5 \mathrm{~km}^{2}$. It is consists of granite and alluvial rocks. Wadi El-Toffaha area is deep, narrow and roughly filled by huge boulders. The height above sea level of site of the stand studies ranges from 1470 to $1620 \mathrm{~m}$. The width of this wadi along area varies from 15 to $20 \mathrm{~m}$. Wadi ElToffaha is containing some gardens.

\section{Wadi Telah}

Wadi Telah (big) basin is surrounding by the main peaks in this area are, Gebel El-Nisheil (2259 m a.s.l.), Gebel Qasr Abbas pasha (2341 m a.s.1.), Gebel Srey (1681 m a.s.1.), Gebel Sommart El-Nisheil (2253 m a.s.1.) and Gebel Ghobsha (1858 m a.s.1.).

\section{Wadi Telah}

Wadi Telah is bound approximately by latitudes $28^{\circ}$ $56^{`}$ to $28^{\circ} 57^{\prime}$ north and longitudes $33^{\circ} 92^{\prime}$ to $33^{\circ} 93^{`}$ east. Wadi Telah is deep, narrow and roughly filled by huge boulder. The bed rocks in wadi Telah are mostly granitic, the main wadi bed and their tributaries are filled with alluvial. The width of wadi Telah along this area varies from 25 to $35 \mathrm{~m}$. The height above sea level of site stand studies ranges from 1520 to $1610 \mathrm{~m}$ a.s.1., that stand studies are location on land form (wadibed, slope and terraces) in this area. Wadi Telah form an area of about $19.75 \mathrm{~km}^{2}$. It is surrounding on all sides by high mountains. Wadi Telah is drained by a number of principal wadis and their tributaries. It is contain some gardens.

\section{Wadi El-Talaa}

It is bound approximately by latitudes $28^{\circ} 561^{\prime}$ to $28^{\circ} 564^{\prime}$ north and longitudes $33^{\circ} 930^{\circ}$ to $33^{\circ} 932^{\circ}$ east. Wadi El-Talaa area is consists of granite and alluvial rocks. The height above sea level of stand studies ranges from 1570 to $1660 \mathrm{~m}$ a.s.l. Wadi El-Talaa forms an area of about $14 \mathrm{~km}^{2}$. The mouth of wadi ElTalaa open from wadi Telah (small), in this area is deep, narrow and roughly filled by huge boulders, width in this area is about $15 \mathrm{~m}$, on the other hand it is above level at middle area and reach on top high at Sid Dawad, it is become very narrow about $3 \mathrm{~m}$ in width. It is contain some gardens.

\section{Wadi Abu-Saila}

It is bound approximately by latitudes $28^{\circ} 591^{\prime}$ to $28^{\circ} 596^{\prime}$ north and longitudes $33^{\circ} 926^{\circ}$ to $33^{\circ} 934^{`}$ east. Abu-Saila area is consists of granite and alluvial rocks. Abu-Saila forms an area is about $2.5 \mathrm{~km}^{2}$. The height above sea level about $1400 \mathrm{~m}$ a.s.l., is made area a good life on people so including many number of Bedouins home, primary school and some gardens. Abu-Saila area is found behind El-Raha plain, the end of this area open in two directions, one directed to wadi Telah and another directed in Nqb El-Hya to El-Tarffa area.

\section{Wadi Gebal}

Wadi Gebal is bound approximately by latitudes $28^{\circ}$ $550^{`}$ to $28^{\circ} 559^{`}$ north and longitudes $33^{\circ} 92^{`}$ to $33^{\circ} 93^{`}$ east. It is consists of granite and alluvial rocks. Wadi Gebal forms an area of about $12 \mathrm{~km}^{2}$. The height above sea level ranges from 1620 to $1920 \mathrm{~m}$, trending on approximate south direction. Wadi Gebal is contents many number of gardens, including or rich by the trees fruit. It is mostly covered by granite rocks forming a mountainous landscape with high peaks raising up to 
$2157 \mathrm{~m}$ a.s.l. Wadi Gebal is beginning at Abu-Guva area, extend to the Taibaq area is contain Ain Sheky which supports all gardens by water. The width of Taibaq in this area is about $50 \mathrm{~m}$, after that extend to Kadid El-Daib in width it is about $35 \mathrm{~m}$, on the other hand the Kadid El-Daib area is extend into known area in this name, Zytonia area, to Abu-Lie, To Hzem Bria, To Abu-Qspa and to Farsh El-Roman area. The width of wadi Gebal along in all this area varies from 30 to $40 \mathrm{~m}$. It is drained by a number of principal wadis and their tributaies.

\section{Wadi El-Sabaiya}

It is consists of wadi El-Sabaiya (small) sub-basin area and wadi Sidood sub-basin area. wadi Sidood area is including wadi Um-Ksum sub sub-basin area

Wadi El-Sabaiya is bound approximately by latitudes $28^{\circ} 57^{`}$ to $28^{\circ} 58^{`}$ north and longitudes $33^{\circ} 98^{`}$ to $33^{\circ}$ $99^{\circ}$ east. It is consists of granite and alluvial rocks, characterized by general gentle slope. Wadi El-Sabaiya forms an area of about $13.75 \mathrm{~km}^{2}$. The height above sea level is about $1450 \mathrm{~m}$, which is a good life for people, so including three village of Bedouins (El-Nasra, AbuMady and El-Sabaiya), primary school, El-Azhr institute and some gardens.

\section{Wadi Sidood}

It is consists of granite and alluvial rocks, characterized by general gentle slope. Wadi Sidood forms an area is about $14 \mathrm{~km}^{2}$. The height above sea level is about $1500 \mathrm{~m}$. It is contain Bedouins home and some gardens. Wadi Sidood sub-basin area is including wadi Um-Ksum sub sub-basin area and is a part of wadiElSabaiya.

In general wadi El-Sabaiya (big) basis are forms an area of about $36.25 \mathrm{~km}^{2}$. It is surrounding by very high Gebel in all sides. Wadi El-Sabaiya is drained by a number of principal wadis and their tributaries, the main drainage of the area is via wadi El-Sabaiya.

\section{Wadi Moktaab}

Wadi Moktaab forms an area of about $6.5 \mathrm{~km}^{2}$. It is consists of granite and alluvial rocks. Wadi Moktaab is wide, general gentle slope and the width of along this area varies from 60 to $80 \mathrm{~m}$. The height above sea level on this wadi about $400 \mathrm{~m}$ a.s.1., made is a good life on people so including of the village of Bedouins, primary school and some gardens. Wadi Moktaab is surrounding by average high mountains, it is drained by a number of principal wadis and their tributaries.

\section{Wadi El-Sheikh}

It is bound approximately by latitudes $28^{\circ} 30^{\circ}$ to $28^{\circ} 47^{`}$ north and longitudes $33^{\circ} 33^{`}$ to $34^{\circ} 00^{\prime}$ east. It consists of igneous and metamorphic rocks. Wadi ElSheikh is about $59 \mathrm{~km}$ long (from the village of Saint Catherine to the Feiran Oasis). The width of wadi ElSheikh along this area varies from 120 to $200 \mathrm{~m}$.

Wadi El-Sheikh forms an area of about $316 \mathrm{~km}^{2}$, it rugged topography with the relief diminishing towards the west. The height, above sea level, ranges from 2637 $\mathrm{m}$ a.s.1 (Gebel Catherine) in the south to about $770 \mathrm{~m}$ a.s.l (Feiran Oasis) in the west. The main peaks in this area are Gebel Catherine $(2637 \mathrm{~m})$, Gebel Abbas Basha (2345 m), Gebel Mousa (2265 m), Gebel Kursi Mousa $(1150 \mathrm{~m})$, Gebel Solsafa $(1570 \mathrm{~m})$ and Gebel Serbal (2070 m).

\section{Wadi Nyssrein}

Wadi Nyssrein forms an area of about $76 \mathrm{~km}^{2}$, it is surrounded in all direction by average high mountains. Wadi Nyssrein is about $8 \mathrm{~km}$ long (from the main road to Bir wadi Nyssrein). The width of wadi Nyssrein along this area varies from 80 to $100 \mathrm{~m}$, at end the wadi became as circle area which it diameter about $120 \mathrm{~m}$. Wadi Nyssrein at circle position, made is a good life people so including many number of Bedouins home, primary school, and some gardens. Wadi Nyssrein is drained by a number of principal wadis and their tributaries, the main drainage of the area is via wadi Nyssrein.

\section{Wadi Saal}

Main basin area is bound approximately by latitudes $28^{\circ} 41^{\prime}$ to $28^{\circ} 48^{\prime}$ north and longitudes $34^{\circ} 3^{\prime}$ to $34^{\circ}$ 16 east. Wadi Saal forms an area of about $108 \mathrm{~km}^{2}$ bound on its eastern and northern sides by Nubian sand stones and in the south by the Zaghra and El-Regata granites. The area consists of met volcanic and met sediment rocks. It is about $25 \mathrm{~km}$ long, trending in approximate east-west direction. Wadi Saal is narrow, often only about $15 \mathrm{~m}$ wide. Eastwards towards Bir Saal, the width becomes 50 to $70 \mathrm{~m}$.

Saal has a reasonable supply of fresh water, with the main water well, Bir Saal in wadi Saal itself, close to the contact of the eastern granites with the Nubian sand stone and on the eastern edge of the area. Saal area is drained by a number of principal wadis and their tributaries. The main drainage of the area is via wadi Saal.

\section{Wadi Solaf}

Main basin area is bound approximately by latitudes $28^{\circ} 61^{\prime}$ to $28^{\circ} 68^{\circ}$ north and longitudes $33^{\circ} 69^{\prime}$ to $33^{\circ}$ $76^{\circ}$ east. The height above sea level ranges from 860 to $950 \mathrm{~m}$. Wadi Solaf consists of granites and alluvial rocks, the bed rocks in this area salty. Wadi Solaf is about $15 \mathrm{~km}$ long (from the main road to Bir Solaf), generally gental slope. Wadi Solaf is a good life suitable people, so it is includes Bir Solaf, many new governmental balding, Bedouins home, primary school and some gardens.

\section{Wadi El-Achdar}

Main basin area is bound approximately by latitudes $28^{\circ} 63^{`}$ to $28^{\circ} 65^{`}$ north and longitudes $33^{\circ} 73^{`}$ to $33^{\circ}$ $75^{\prime}$ east. It consists of granites and alluvial rocks, the bed rocks in wadi El-Akhdar are diuretic. The height above sea level ranges from 1250 to $1320 \mathrm{~m}$. Wadi ElAchdar is containing small primary school, few Bedouins home and some small gardens.

\section{Sheikh Awad}

Basin area is bound approximately by latitudes $28^{\circ}$ $76.0^{\circ}$ to $28^{\circ} 76.2^{\circ}$ north and longitudes $33^{\circ} 94.6^{\circ}$ to $33^{\circ}$ $94.8^{`}$ east. It consists of granites and alluvial rocks The height above sea level ranges from 1090 to $1160 \mathrm{~m}$. 
Sh.Awad basin is consider circular area, diameter about $300 \mathrm{~m}$. It is contain small primary school, much number of Bedouins home and some gardens.

\section{MATERIALS AND METHODS}

The present study included 317 stands in twenty-two wadis in southern Sinai, located on three different landforms; wadi beds, slopes and terraces. Soil samples were collected from three plots in each of the 317 stands as shown Table 1, one soil sample was chosen from three plots in each of the 317 stands for all wadis studies in southern Sinai. The soil samples were collected from depth $0-25 \mathrm{~cm}$. The collected soil samples were subjected for quantitative physical and chemical analyses.

\section{Soil physical analysis}

In laboratory, soil samples were air dried, and sieved by a $2 \mathrm{~mm}$ sieve to evaluate gravel percent. By sieving method, fine soil fractions were determined using the following sieve meshes: gravel (>2 mm), coarse sand $(0.59 \mathrm{~mm})$, medium sand $(0.25 \mathrm{~mm})$, fine sand $(0.063$ $\mathrm{mm})$ and silt + clay $(<0.063 \mathrm{~mm})$. The organic matter content of soil samples was determined by loss on ignition. Ten grams of $2 \mathrm{~mm}$-mesh sieved oven dried soil, are placed in a $4{ }^{\circ} \mathrm{C}$ tarred porcelain crucibles and ignited in an electric muffle furnace at $600{ }^{\circ} \mathrm{C}$ for about three hours. The crucibles were placed in a desiccator, cooled to room temperature, and weighed. Loss is calculated in percent of the oven dried sample.

Soil samples were weighed in a tarred aluminum container each, placed in oven, and dried to content weight at $105^{\circ} \mathrm{C}$. Then the samples were reweighed, and the content of moisture was expressed as a percentage of the oven dry weight (Wilde et al., 1972).

\section{Soil chemical analysis}

The $\mathrm{pH}$ values of water extracts of soil samples (in ratio 2:1) were measured using a $\mathrm{pH}$ meter following the method of Allen et al., (1976). Specific conductivity (E.C.), the reciprocal of specific resistance, was measured in a conductivity cell by a low voltage A.C. Wheat stone bridge (EC meter) as described by Wilde $e t$ al., (1972).

Sixty-four soil samples were selected to represent the studied wadis. Chemical analysis was performed using standard techniques in the central laboratory of the Forest Ecosystems Research Centre at Goettingen University. For cations and $\mathrm{So}_{4}{ }^{-} \mathrm{S}$ in the soil extracts $(1: 2$ soil/water ratio), the ICP-OES-technique was used (instrument reference: Spectro Analytical Instruments, Kleve, Germany); for $\mathrm{NH}_{4}{ }^{-} \mathrm{N}$ and $\mathrm{NO}_{3}{ }^{-} \mathrm{N}$ in solution continuous flow injection colorimetric was applied (instrument reference: Skalar, Erkelenz, Germany); for total $\mathrm{C}$ and $\mathrm{N}$ in soil (after drying at $60{ }^{\circ} \mathrm{C}$ and grinding to a fine power), we used a $\mathrm{C}$-N-analyser (instrument reference: CHN-O-Rapide, VarioEL, Elementar, Germany). The standard deviation of $\mathrm{C}$-and $\mathrm{N}$-measurements is $0.1 \%$ (abs.), our detection limit for plant and soil material is $1 \mathrm{mg}$ for total $\mathrm{N}$ and $0.1 \mathrm{mg} \mathrm{g}^{-1}$ for total $\mathrm{C}$ content. Sub-samples, for all samples collected, were dried at $105{ }^{\circ} \mathrm{C}$ to determine the water contents of samples, i.e. given element contents are related to $105{ }^{\circ} \mathrm{C}$ dry weights.

Element analyses were carried out using standard methods: The cation exchange capacity (CEC) was determined by percolating (6h) $2.5 \mathrm{~g}$ of dried $\left(40{ }^{\circ} \mathrm{C}\right)$ and sieved $(2 \mathrm{~mm})$ soil with $1 \mathrm{~N} \mathrm{NH} \mathrm{Cl}$. Cations $\left(\mathrm{Na}, \mathrm{K}^{+}\right.$, $\mathrm{Ca}^{2+}, \mathrm{Mg}^{2+}=\mathrm{M}_{\mathrm{b}}$, basic cations; $\mathrm{Al}^{3+}, \mathrm{Fe}^{3+}, \mathrm{Mn}^{2+}=\mathrm{M}_{\mathrm{a}}$, acid cations) in the percolate were determined with the atomic absorption spectrophotometry (AAS, Varian Spectra 300A, Varian, Darmstadt, Germany).

Humus samples (300 to $400 \mathrm{mg}$ ) were digested after drying $\left(60^{\circ} \mathrm{C}\right)$ and sieving $(2 \mathrm{~mm})$ with $2 \mathrm{ml}$ of $\mathrm{HNO}$ in Teflon digestion bombs $(5 \mathrm{~h})$. Here cations, total $\mathrm{P}(\mathrm{P})$ and total $S\left(S_{t}\right)$ were measured with the inductive coupled plasma atomic emission spectroscope technique (ICP-AES, Spectroflame, Spectro Analytical Instruments, Kleve, Germany). Total $\mathrm{N}\left(\mathrm{N}_{\mathrm{t}}\right)$ and $\mathrm{C}\left(\mathrm{C}_{\mathrm{t}}\right)$ were determined by a $\mathrm{C} / \mathrm{N}$ - analyser (CHN-O-Rapide, VarioEL, Elementar, Germany). All given element concentrations are related to the absolute dry weight $\left(\mathrm{dw}, 105{ }^{\circ} \mathrm{C}\right)$.

\section{Vegetation analysis}

In each wadi the stands were selected to represent major apparent variations in the physiognomy of vegetation and in topographic and edaphic features. Each stand area was measured by rope $15 \times 10 \mathrm{~m}$ in area. In each stand, the following parameters were measured; altitude (in meters above sea level) by altimeter instrument, location (north, east) by G.P.S. Instrument, slope degree, exposure degree by chump's instrument, rock unit and landform type. Landform type was determined according to Moustafa \& Klopatek (1995) as; (gorge, slopes, terraces, ridges, wadi beds, and plains). Nature of soil surface was described using the following scale; fine fraction $(<2 \mathrm{~mm})$, gravel (2$75 \mathrm{~mm})$, cobbles $(75-250 \mathrm{~mm})$, stones $(250-600 \mathrm{~mm})$, and boulders (> $600 \mathrm{~mm}$ ), (Hausenbiuller, 1985).

In each stand, the species list was recorded. The following parameters were measured; perennials and annuals present in each stand were recorded, plant nomenclature according to (Täckholm, 1974), plant cover was measured in $\mathrm{cm}^{2}$ while height in $\mathrm{cm}$.

Species richness refers to the total number of species in some area within a community. The distribution of individuals among the species is called species evenness. Species diversity is a combination of richness and evenness.

Species list including the individual number of each species per each stand was recorded to calculate species richness and species diversity indices. These indices were calculated using EcoSim 7.22 software. Species diversity of each stand was calculated using Shannon Diversity index (H') (Barbour et al., 1987).

\section{Results}

\section{Floristic composition}

Throughout the studied stands, one hundred and sixty-four species were identified belonging to forty 


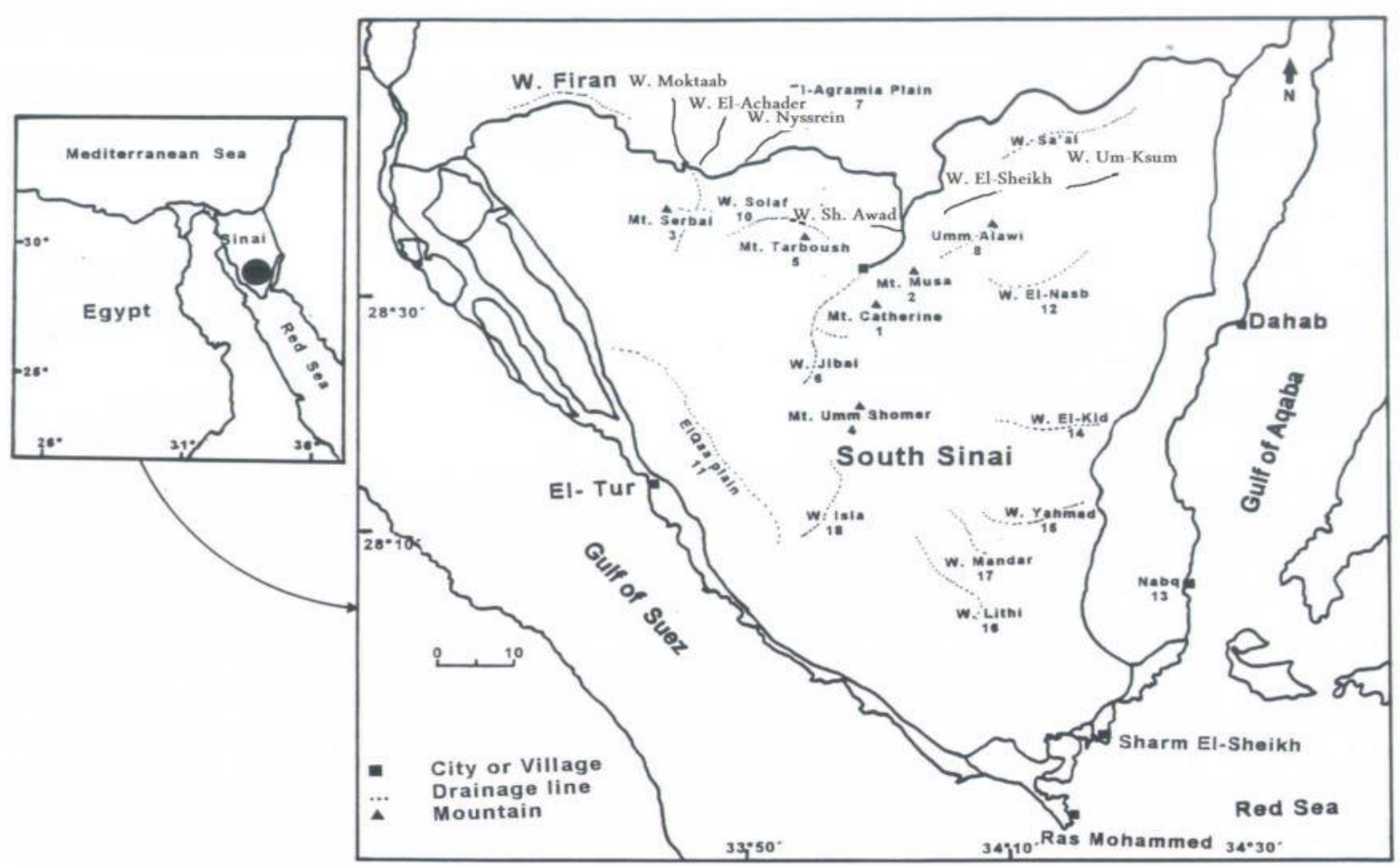

Figure (1): Map shows the location of the study area in south Sinai.

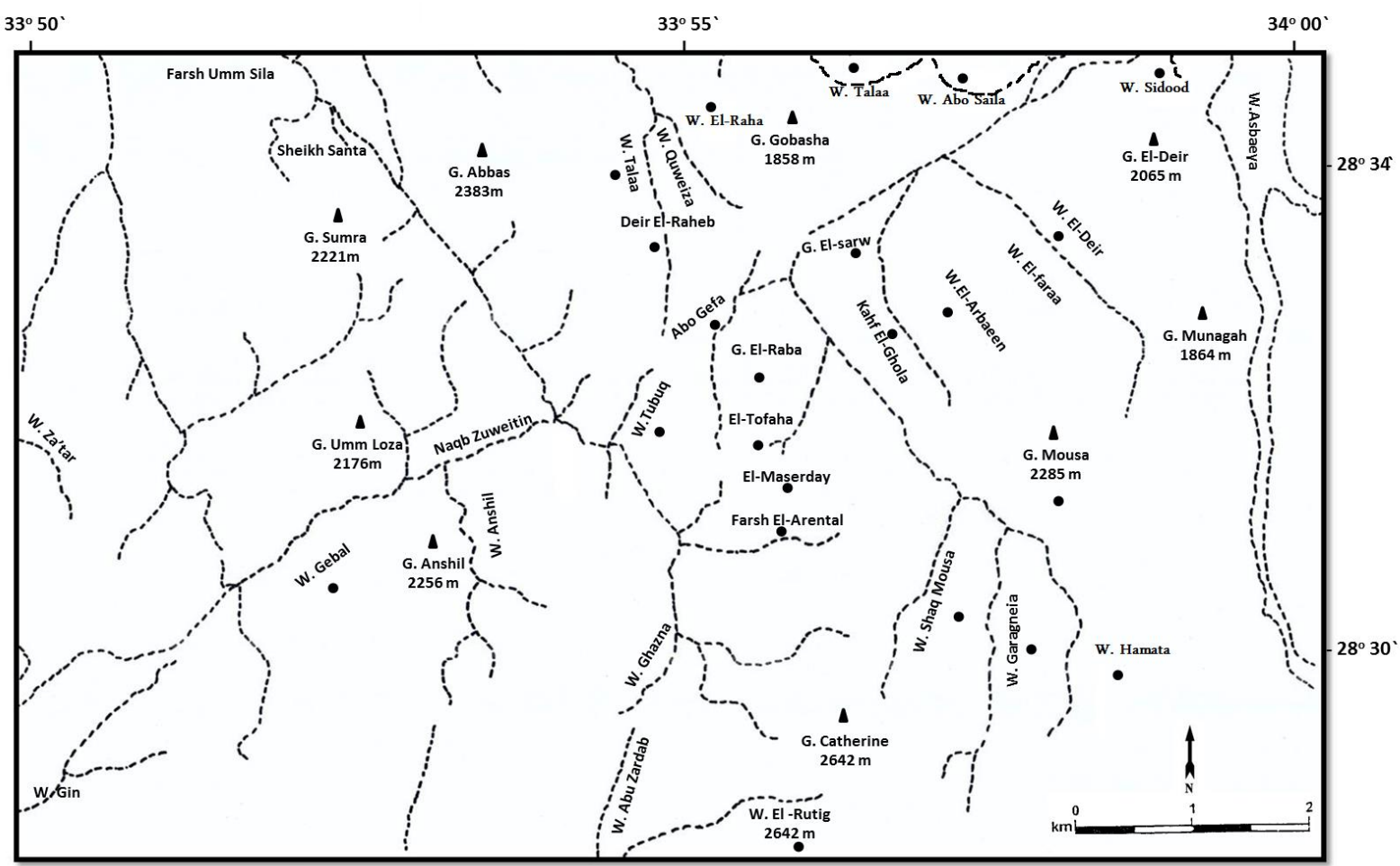

Figure (2): Location map of the study area (Saint Catherine Protectorate) in the southern part of Sinai. Mountain tops (Mt.) are represented by $(\boldsymbol{\Delta})$, Wadis or valleys $(\mathrm{W})$ and locations of the studied areas represented by $(\bullet)$. 
Table (1): Shows the number of selected stands in each wadi.

\begin{tabular}{lccc}
\hline \hline Wadi name & No. of stands. & Wadi name & No. of stands. \\
\hline EL-Arbain & 51 & Jebal & 11 \\
Shaq-Mouse & 5 & EL-Sbayia & 13 \\
Gragnia & 5 & Sidood & 6 \\
Hamata & 5 & Um-Ksum & 7 \\
EL-Faraa & 13 & Saal & 21 \\
EL-Toffaha & 13 & EL-Achader & 10 \\
EL-Raha & 23 & Solaf & 15 \\
EL-Dair & 37 & EL-Sheikh & 21 \\
EL-Talaa & 10 & Nyssrein & 15 \\
Telah & 10 & Moktaab & 6 \\
Abo Saila & 10 & Sheikh. & 10 \\
\hline \hline
\end{tabular}

three families. The most represented families were: Comositae, Labiatae, Leguminosae, Gramineae, Caryophyllaceae, Scrophulariaceae and Rubiaceae. While Adiantaceae, Acanthaceae, Amaranthaceae, Campanolaceae,Capparaceae,Cistaceae,Convolvulaceae,Cucurbitaceae,Cyperaceae, Dipsacaceae, Ephedraceae, Equisetaceae, Geraniaceae, Guttiferae, Juncaceae, Liliaceae, Malvaceae, Menispermaceae, Plantaginaceae, Polygonaceae, Primulaceae, Tamariceceae and Urticaceae are represented by only one species for each. Six life-forms were recognized: chamaephytes, hemicryphytes, therophytes (annuals), perennial grasses, phanerophytes, and geophytes with the former being the most dominant $(46.95 \%)$ followed by the therophytes $(30 \%)$ and hemicryphytes $(12.19 \%)$.

\section{Classification of stands}

Based on the floristic composition (cover percent), the stands could be classified and separated, at the third level, by TWINSPAN to seven main communities.

Community I. Zilla spinosa

I I. Alkanna orientalis - Varthemia montana

I I I. Alkanna orientalis - Stachys aegyptiaca

I V. Artemisia judaica - Achillea fragrantissima

V. Hammada elegans

V I. Artemisia judaica

V I I. Acacia tortilis

\section{Community I. Zilla spinosa}

This community represented 13 stands. Zilla spinosa L. is the dominant species. Artemisia judaica Asso.,

Table (2): Species list (according to Bolous, 1995), and life form (according to Danin, 1983; Moustafa, 1990; Moustafa \& Kamel, 1996, and Moustafa \& Zaghloul, 1997). CH-chamaephyte or shurb; G-geophyte; Hhemicryptophyte; Pg-perennial grass; \& Ph-phanerophyte.

\begin{tabular}{|c|c|c|}
\hline Family & Specis Name & Life form \\
\hline Adiantaceae & Adiantum capillus-veneris $\mathrm{L}$. & $H$ \\
\hline Acanthaceae & Blephoris ciliaris (L.) Burtt & $A n$ \\
\hline Amaranthaceae & Aerva javanica (Burm. F.) & $\mathrm{CH}$ \\
\hline \multirow[t]{3}{*}{ Asclepiadaceae } & Asclepias sinaica (Boiss.)Muschl & $\mathrm{CH}$ \\
\hline & Calotropis procera (Ait.) & $\mathrm{CH}$ \\
\hline & Perguloria tomentosa $\mathrm{L}$. & $\mathrm{CH}$ \\
\hline \multirow[t]{5}{*}{ Boraginaceae } & Alkanna orientalis (L.) Boiss & $\mathrm{CH}$ \\
\hline & Heliotropium arbainense Fres. & $\mathrm{CH}$ \\
\hline & Micorparacaryum intermedium (Fresen)Hilge\&Podl. & $H$ \\
\hline & Paracaryum intermedium (Fresen)Lipsky & $A n$ \\
\hline & Trichodesma africanum (L.) R. Br. & \\
\hline \multirow{10}{*}{$\begin{array}{l}\text { Campanolaceae } \\
\text { Capparaceae } \\
\text { Caryophyllaceae }\end{array}$} & Camnanula dulcis Decene & $\mathrm{CH}$ \\
\hline & Capparis orientalis Duh. & $\mathrm{CH}$ \\
\hline & Arenaria deflexa Decne. & $H$ \\
\hline & Gymnocarpos decander (Forssk) & $\mathrm{CH}$ \\
\hline & Gypsophila capilloris (Forssk)C.Chr.Subspconfusa Zmarzty & $\mathrm{CH}$ \\
\hline & Minuartia meyeri (Boiss).Bornn. & $A n$ \\
\hline & Paronychia sinaica Fresen & $\mathrm{CH}$ \\
\hline & Silene conoidea $\mathrm{L}$. & $A n$ \\
\hline & Silene linearis Decne. & $A n$ \\
\hline & Silene sp. & $A n$ \\
\hline
\end{tabular}




\begin{tabular}{|c|c|c|}
\hline Family & Specis Name & Tife form \\
\hline & Atriplex semibaccata R.Br. & $A n$ \\
\hline & Hammada elegans (Bunge) Botsch & $\mathrm{CH}$ \\
\hline Cistaceae & Helianthemum kahiricum Del. & $\mathrm{CH}$ \\
\hline \multirow[t]{4}{*}{ Cleomaceae } & Cleome africana (Botsh) & $A n$ \\
\hline & Cleome amblyocarpia Barratte\&Murb. & $A n$ \\
\hline & Cleome arabica $\mathrm{L}$. & $A n$ \\
\hline & Cleome afracna & $A n$ \\
\hline \multirow[t]{26}{*}{ Compositae } & Achillea fragrantissima (Forssk.)Sch.Bip & $H$ \\
\hline & Artemisia inculta Asso & $\mathrm{CH}$ \\
\hline & Artemisia judaica Asso & $\mathrm{CH}$ \\
\hline & Centaurea scoporia & $\mathrm{CH}$ \\
\hline & Centourea eryngioides Lam & $\mathrm{CH}$ \\
\hline & Conyza bonariensrs $(\mathrm{L}$.$) Cronquist$ & $A n$ \\
\hline & Crepis sancta (L.) Bornum. & $A n$ \\
\hline & Echinops glaberrimus Dc. & $H$ \\
\hline & Filago desertorm Pomel & $A n$ \\
\hline & Helichrysum orientale $\mathrm{L}$. & $A n$ \\
\hline & Ifloga spicata (Fossk.)Sch.Bipin Ebb\&Berthel subsp.spicata & $A n$ \\
\hline & Iphiona scabra Dc. & $\mathrm{CH}$ \\
\hline & Inula crithmoides $\mathrm{L}$. & $\mathrm{CH}$ \\
\hline & Lactuca orientalis (Boiss.) Boiss. & $\mathrm{CH}$ \\
\hline & Launaea nudicaulis (L.) Hook.f. & $\mathrm{CH}$ \\
\hline & Launaea spinosa (Forssk.) & $\mathrm{CH}$ \\
\hline & Leysera leyseroides (Desf.) Maire & $A n$ \\
\hline & Onopordum атbiguит Fresen & $H$ \\
\hline & Phagnalon nitidum Fresen & $\mathrm{CH}$ \\
\hline & Pulicaria arabica (Forssk.) Oliv. & $\mathrm{CH}$ \\
\hline & Pulicaria undulata (Forssk.) Oliv. & $\mathrm{CH}$ \\
\hline & Pulicaria crispa (Forssk.) Oliv. & $\mathrm{CH}$ \\
\hline & Reichardia tingitana $(\mathrm{L}$.$) Roth$ & $A n$ \\
\hline & Senecio sp. & $A n$ \\
\hline & Tanacetum santolinoides (Dc.)Feinbrum\&Fertig & $\mathrm{CH}$ \\
\hline & Varthemia montana (Vahl) Boiss. & $\mathrm{CH}$ \\
\hline Convolvulaceae & Convolvulus arvensis $\mathrm{L}$. & $\mathrm{CH}$ \\
\hline \multirow[t]{6}{*}{ Cruciferae } & Diplotaxis harra (Forssk.)Boiss. & $H$ \\
\hline & Farsetia aegyptia Turra & $\mathrm{CH}$ \\
\hline & Matthiola arabica Boiss & $\mathrm{CH}$ \\
\hline & Morettia conescens Boiss & $H$ \\
\hline & Sisymbrium irio L. & $A n$ \\
\hline & Zilla spinosa (L.) Prantl subsp.spinosa & $\mathrm{CH}$ \\
\hline Cucurbitaceae & Citrullus colocynthis (L.) Schrad & $A n$ \\
\hline Cyperaceae & Cyperus sp. & $P g$ \\
\hline Dipsacaceae & Pterocepholus sanctus Decne & $\mathrm{CH}$ \\
\hline Ephedraceae & Ephedra alata Decne & $\mathrm{CH}$ \\
\hline Equisetaceae & Equasetaium ramossissimum Desf. & $\mathrm{CH}$ \\
\hline \multirow[t]{3}{*}{ Euphoibiaceae } & Androchne aspera Spreng & $H$ \\
\hline & Eupharbia retusa Forssk. & $\mathrm{CH}$ \\
\hline & Eupharbia Sinaica Hadidi & $\mathrm{CH}$ \\
\hline \multirow[t]{8}{*}{ Geraniaceae } & Erodium laciniatum (Cav.)Willd & $H$ \\
\hline & Artistida adscensionis $\mathrm{L}$ & $A n$ \\
\hline & Avena fatua $\mathrm{L}$. & $A n$ \\
\hline & Bromus pectinatus Thumb & $A n$ \\
\hline & Bromus tectorum L. & $A n$ \\
\hline & Cynodon dactylon (L.)Pers. & $P g$ \\
\hline & Hyparrhenia hirta (L.) Staef & $\mathrm{Pg}$ \\
\hline & Lolium rigidum Gaudin & $A n$ \\
\hline \multirow{8}{*}{ Graminae } & Oryzopsis miliacea (L.) Asch.\&Schweinf. & $P g$ \\
\hline & Pennisetum glaucum (L.)R.Br. & $A n$ \\
\hline & Polypogon viridis (Gouan)Breistr. & $A n$ \\
\hline & Schismus barbatus (L.) Thell. & $A n$ \\
\hline & Sorghum virgatum (Hack.)Stepf & $A n$ \\
\hline & Stipa pariviflora Desf. & $P g$ \\
\hline & Stipagrostis raddiano (Savi)de Winter & $P g$ \\
\hline & Vulpia myuros (L.)C.C.Grnel. & $A n$ \\
\hline Guttiferae & Hypericum sinaicum Boiss & $H$ \\
\hline \multirow[t]{2}{*}{ Juncaceae } & Juncus rigidus Desf. & $H$ \\
\hline & Ajuga chamaepitys $(\mathrm{L}$.$) Suhreb.subsp.tridactylites(Benth.)pH.Davis$ & $H$ \\
\hline \multirow{3}{*}{ Labiatae } & Ballota kaiseri Tackh. & $\mathrm{CH}$ \\
\hline & Ballota saxatilis C.Presl subsp.saxatilis & $\mathrm{CH}$ \\
\hline & Ballota undulata (Fresen.)Benth. & $\mathrm{CH}$ \\
\hline
\end{tabular}


Moustafa et al.

\begin{tabular}{|c|c|c|}
\hline Family & Specis Name & Life form \\
\hline & $\begin{array}{l}\text { Lavandula coronopifolia Poir } \\
\text { Lavandula pubescens Decne } \\
\text { Lavandula stricta } \text { Del. } \\
\text { Marrubium alysson } \text { L. } \\
\text { Mentha longifolia } \text { (L.) Huds. } \\
\text { Mentha microphylla } \text { C. Koch } \\
\text { Nepeta septemcrenata Benth. } \\
\text { Origanum syriacum } \text { L. subsp.sinaicum } \text { (Boiss.)Gteuter\&Pordet } \\
\text { Phlomis aurea } \text { Decne } \\
\text { Salvia sp. } \\
\text { Stachys aegyptiaca } \text { Pers } \\
\text { Teucrium decaisnei } \text { C.Presl } \\
\text { Teucrium leucocladum Boiss } \\
\text { Teucrium polium } \text { L. }\end{array}$ & $\begin{array}{l}\mathrm{CH} \\
\mathrm{CH} \\
\mathrm{CH} \\
\mathrm{An} \\
\mathrm{H} \\
\mathrm{H} \\
\mathrm{CH} \\
\mathrm{CH} \\
\mathrm{CH} \\
\mathrm{CH} \\
\mathrm{CH} \\
\mathrm{CH} \\
\mathrm{CH} \\
\mathrm{CH}\end{array}$ \\
\hline Leguminosae & Acacia raddiana Savi & $A n$ \\
\hline & $\begin{array}{l}\text { Astragalus asterias Steven subsp.radiatus (Batt)Greuter } \\
\text { Astragalus bombycinus Boiss } \\
\text { Astragallus spinosus } \\
\text { Bituminaria bituininosa (L.)C.H.Stirt. } \\
\text { Cassia italica (Mill.) Lam. } \\
\text { Crotaloria aegyptiaca } \text { Benth. } \\
\text { Lotononis platycorpa } \text { (Viv.)pic.Serm } \\
\text { Lygos raetam (Forssk.) } \\
\text { Tephrosia nubica (Boiss.) Baker } \\
\text { Trigonella stellata Forsk. } \\
\text { Vicia narbonensis } \text { L. }\end{array}$ & $\begin{array}{l}\mathrm{An} \\
\mathrm{An} \\
\mathrm{An} \\
\mathrm{CH} \\
\mathrm{CH} \\
\mathrm{CH} \\
\mathrm{An} \\
\mathrm{CH} \\
\mathrm{CH} \\
\mathrm{An} \\
\mathrm{An}\end{array}$ \\
\hline Liliaceae & Muscari sp. & Per. \\
\hline Malvaceae & Malva parviflora $\mathrm{L}$. & $A n$ \\
\hline Menispermaceae & Cocculus pendulus (J.R \& G.Forst.) Diels & $A n$ \\
\hline Moraceae & $\begin{array}{l}\text { Ficus carica } \mathrm{L} \text {. } \\
\text { Ficus palmata } \text { Forssk. }\end{array}$ & $\begin{array}{l}P h \\
P h\end{array}$ \\
\hline Papaveraceae & $\begin{array}{l}\text { Glaucium arabicum Fres. } \\
\text { Glaucium corniculatum (L.) J. H. Ruddph. } \\
\text { Papaver decaisnei Elkan } \\
\text { Papaver rhoeas } \text { L. }\end{array}$ & $\begin{array}{l}H \\
H \\
A n \\
A n\end{array}$ \\
\hline Plantaginaceae & Plantago sinaica (Barneoud) Decne. & $\mathrm{CH}$ \\
\hline Polygonaceae & Rumex cyprirs Murb. & $A n$ \\
\hline Primulaceae & Primula bovenna Duby & $H$ \\
\hline Resedaceae & $\begin{array}{l}\text { Caylusea hoxagyna (Forssk)M.L.Green } \\
\text { Ochradenus baccatus Del. } \\
\text { Reseda pruinosa Del. }\end{array}$ & $\begin{array}{l}G \\
C H \\
A n\end{array}$ \\
\hline Rosaceae & $\begin{array}{l}\text { Cotoneaster orbicularis Schlecht. } \\
\text { Crataegus sinaica Boiss } \\
\text { Rosa arabica Crep. }\end{array}$ & $\begin{array}{l}\mathrm{CH} \\
\mathrm{Ph} \\
\mathrm{Ph}\end{array}$ \\
\hline Rubiaceae & $\begin{array}{l}\text { Callipeltis cucullaris (L.) Steven } \\
\text { Crucianella ciliata Lam } \\
\text { Crncianella membranacea Boiss. } \\
\text { Galium parisiense L. } \\
\text { Galium setaceum Lam } \\
\text { Galium sinaicum (Delile ex Decne.)Boiss. } \\
\text { Haplophyllum tuberculatum (Forssk.) A. juss. } \\
\text { Anarrhinum pubescens Fresen } \\
\text { Bufouia multiceps Decne. }\end{array}$ & $\begin{array}{l}A n \\
A n \\
A n \\
A n \\
A n \\
A n \\
A n \\
H \\
C H\end{array}$ \\
\hline Scrophulariaceae & Kickxia mailenta (Decne.)Danin & $H$ \\
\hline & Scrophuloria sp. & $\mathrm{CH}$ \\
\hline Solonaceae & $\begin{array}{l}\text { Verbascum decaisneanan Benth. } \\
\text { Verbascum sinaiticum Kuntze } \\
\text { Hyoscymus muticus L. } \\
\text { Lycium shawii Roem. Et Sch. }\end{array}$ & $\begin{array}{l}\mathrm{CH} \\
\mathrm{CH} \\
\mathrm{CH} \\
\mathrm{CH}\end{array}$ \\
\hline Tamariceceae & $\begin{array}{l}\text { Solanum nigrum } \mathrm{L} . \\
\text { Reaumuria vermiculata } \mathrm{L} .\end{array}$ & $\begin{array}{l}\mathrm{An} \\
\mathrm{CH} .\end{array}$ \\
\hline Umbelliferae & $\begin{array}{l}\text { Ammi majus L. } \\
\text { Bupleurum falcatum L. } \\
\text { Deverra triradiata Hochst.ex Boiss. } \\
\text { Pituranthos tortuosus (Desf.) Benth. \& Hook. F. } \\
\text { Pituranthos triradiatus (Hochst.) Asch. \& Schweinf. } \\
\text { Parietaria alsinifolia Delile }\end{array}$ & $\begin{array}{l}\mathrm{An} \\
\mathrm{CH} \\
\mathrm{CH} \\
\mathrm{CH} \\
\mathrm{CH} \\
\mathrm{An}\end{array}$ \\
\hline Zygophyliaceae & $\begin{array}{l}\text { Fagonia arabica L.v.viscidissima Maire } \\
\text { Fagonia mollis Delile }\end{array}$ & $\begin{array}{l}\mathrm{CH} \\
\mathrm{CH}\end{array}$ \\
\hline
\end{tabular}


Aerva javanica Burm.F. Fagonia mollis Delile and Peganum harmala $\mathrm{L}$. are the codominant species, while Achillea fragrantissima Forssk. Varthemia Montana Boiss., Kickxia macilenta Decne. Lavandula stricta Del and Diplotaxis harra Forssk. are the most prominent associated species. This community is restricted in wadi Saal and wadi El-Sheikh. Altitude ranges from 1270 to $1410 \mathrm{~m}$ a.s.1..The nature of soil surface is gravely ranges from 14 to $26.67 \%$ and boulders ranges $0-28.33 \%$. Soil texture is coarse sand ranges between 20.58 $76.55 \%$. Found in two assemblages.

\section{Community I I. Alkanna orientalis - Varthemia montana}

This vegetation community is the most common in Saint Catherine area. It was represented by 53 stands. Alkanna orientalis Tausch. and Varthemia montana Boiss. Were the dominant species Plus, Phlomis aurea Decne. Stachys aegyptiaca Pers. and Achillea fragrantissima Forssk. Were the co-dominant species, while, Origanum syriacum Boiss, Teucrium polium L. and Artemisia herb-alba L. were the most prominent associated species. This community is restricted to high elevated area in south Sinai and represented in Saint Catherine area and elevated wadis (e.g. wadi Gragnia, wadi El-Arbain and wadi Telah). These sites have such elevation ranges between $1300-1930$. The nature of soil surface is gravely ranges $(5.7-23.33 \%)$ and boulders ranges $(4-41.7 \%)$. Soil texture is coarse sand ranges between $16.29-64.42 \%$.

\section{Community I I I. Alkanna orientalis - Stachys aegyptiaca}

Alkanna orientalis L. and Stachys aegyptiaca Pers are the dominant species. Asclepias sinaica Boiss. is the codominant species, while Peganum harmala L. and Teucrium polium L. are the most prominent associated species. This community can be found in elevated areas of Saint Catherine (e.g. wadi Hammata, wadi Talaa) and surrounding between $(1290-1900 \mathrm{~m}$. a.s.l.). The nature of soil surface is gravely ranges between $(5-56.67 \%)$ and boulders ranges $(0-35 \%)$. Soil texture is coarse sand ranges $(3.9-67.5 \%)$.

\section{Community I V. Artemisia judaica- Achillea fragran- tissima}

Artemisia judaica Asso. and Achillea fragrantissima Forssk. are the dominant species. Peganum harmala L. and Fagonia mollis Delile. Are the codominant species, while Alkanna orientalis Boiss. Varthamia Montana Boiss. And Artemisia herb-alba is the most prominent associated species. This community can be found in elevated areas of Saint Catherine (e.g. wadi El-Raha and wadi El-Dair). These sites have such elevation ranges between 1140 to 1630 m.a.s.l. The nature of soil surface is gravely ranges $(4.33-60.33 \%)$ and boulders ranges $(0-25 \%)$. Soil texture is coarse sand ranges $(23.78-$ $64.39 \%)$.

\section{Community V. Hammada elegans}

Hammada elegans Baunge. Is the dominant speacies Hyocymus muticus L. and Lygos raetam Forssk. Are the codominant species, while Artemisia judaica Asso. And
Peganum harmala L. are the most prominent associated species. This community is mainly found in open valleys of sandy and gravely soil surface, (e.g. wadi Solaf and wadi El-Sheikh). These sites have such elevation ranges between 400 to 1470 m.a.s.l. The nature of soil surface is gravely $(13.33-26.67 \%)$ and boulders ranges $(0-23.33 \%)$. Soil texture is coarse sand ranges $(31.91-60.33 \%)$.

\section{Community V I. Artemisia judaica}

Artemisia judaica L. is the dominant species. Anabasis articulta Adans. Lygos raetam Adans. and Hammada elegans Baunge. are the codominant species, while Zilla spinosa Forssk. and Hyoscumus muticus L. are the most prominent associated species. This community is restricted to wadi El-Achder and wadi ElSabaiya. Altitude ranges from $(440-1400$ m.a.s.l.). The nature of soil surface is gravely ranges $(5.67-28.33 \%)$ and boulders ranges $(0-18.33 \%)$. Soil texture is coarse sand ranges between 21.58 to 59.11 .

\section{Community V I I. Acacia tortilis}

Acacia tortilis Mill. is the dominant species. Hammada elegans Baunge. is the codominant species, while Lycium shawii L. is the most prominent associ-ated species. This community types is widely distributed through south Sinai except Saint Catherine area. Acacia tortilis Mill. is mainly present near the foothills and sometimes on slopes of metamorphic mountains. This community is restricted to wadi Nyssrein, wadi Moktaab and wadi El-Sheikh. These sites have such elevation ranges between 400 to 1000 m.a.s.l. The nature of soil surface is gravely ranges (13.33 $26.67 \%)$ and boulders ranges $(0-20 \%)$. Soil texture is coarse sand ranges $(25.69-49.44 \%)$.

\section{Vegetation variations and environmental factors}

By Tukey's test, the altitudinal gradient decrease from Saint Catherina area going eastward till Gulf of Aqaba and westward till Gulf of Suez. Community III Alkanna orientalis - Stachys aegyptiaca show the highest mean values in altitude $1610.67 \mathrm{~m}$., while community V Hammada elegans show the lowest mean values in altitude $722.66 \mathrm{~m}$. Community I Zilla spinosa, IV Artemisia judaica - Achillea fragrantissima shows the mean value are $1346.15 \mathrm{~m}, 1493.70 \mathrm{~m}$ respectively. Community VII Acacia tortilis, VI Artemisia judaica shows the mean value are $801.25 \mathrm{~m}, 1151.87 \mathrm{~m}$ respectively.

Nature of soil surface of the studied area, revealed that fine soil showed the highest mean values $54.35 \%$ in community VI Artemisia judaica, while it had the lowest mean values $31.77 \%$ in community II Alkanna orientalis - Varthemia montana. Gravel showed the highest mean values $22.91 \%$ in community VII Acacia tortilis; while it had the lowest mean values in $15.66 \%$ community II Alkanna orientalis - Varthemia montana. Furthermore, stones showed the highest mean values in $18.11 \%$ in Community II Alkanna orientalis - Varthemiamontana, while the lowest mean values in stone was $8.84 \%$ in community VI Artemisia judaica. Finally, boulder showed the highest mean values of $18.52 \%$ in 
Community II Alkanna orientalis - Varthemia montana, while it showed the lowest mean values of $2.32 \%$ in community V I Artemisia judaica.

All community's $\mathrm{pH}$ mean values ranged between (7.87- 8.38), while soil moisture content mean values ranged between (1.05-1.98\%).

Plant cover showed the highest mean value of $2.58 \%$ in community II in Alkanna orientalis - Varthemia montana, while it showed the lowest mean value of 0.40 $\%$ in community VII Acacia tortilis. In addition, species richness recorded the highest means value was $5.867 \%$ in community II Alkanna orientalis - Varthemia montana, while the lowest was $2.13 \%$ in community V Hammada elegans. On the other hand, species diversity (Shannon index), showed that the highest mean value was $3.29 \%$ in Community III Alkanna orientalis Stachys aegyptiaca, while the lowest was $1.17 \%$ in community V Hammada elegans. Meanwhile, species diversity (Margalef index), showed that the highest mean values of species diversity $4.36 \%$ in Community VII Acacia tortilis, while the lowest value was $0.21 \%$ in community V Hammada elegans.

\section{Vegetation properties and environmental variables relationships}

In this section, relationships between vegetation properties and number of environmental variables including physiographic parameters and soil features were tested using correlation analysis.

Based on correlation test of Physiographic parameters and soil physical variables, altitude, and slope have a direct relation with nature of soil surface and the fractions of the soil. Altitude has a positive correlation with large soil surface fragments, stone $(r=0.266)$, and negative correlation with gravel $(\mathrm{r}=-0.208)$. Altitude has a positive correlation with large fragments of soil texture fine sand $(r=0.175)$, and negative correlation with medium sand $(r=-0.359)$. Altitude has a positive correlation with soil moisture content $(r=0$.303). Slope shows positive correlation with boulder fraction $(\mathrm{r}=$ $0.124)$, whereas negative correlation with fine soil in nature of soil surface $(r=-0.141)$.

Pearson correlation matrix of some soil physical and chemical properties indicates an obvious interaction between soil properties. There was a highly significant correlation between soil properties such as $\mathrm{K}$ with $\mathrm{NH}_{4}$, $\mathrm{Ca}, \mathrm{Mg}, \mathrm{Mn}, \mathrm{So}_{4}, \mathrm{Cl}, \mathrm{No}_{3}$, Total $\mathrm{N}$, and Or. N ( $\mathrm{r}=$ $0.695,0.432,0.433,0.490,0.733,0.384,0.415,0.443$ and 0.678 respectively).

\section{Vegetation properties and soil variables}

Vegetation Properties; Plant cover, species richness and species diversity (Shannon index and Margalef index) were positively correlated with altitude, slope, gravel, stones, boulders, medium sand, silt \& clay, $\mathrm{pH}$, $\mathrm{pH} \mathrm{KCl,} \mathrm{Soil} \mathrm{moisture} \mathrm{content} \mathrm{and} \mathrm{Fe.}$

Total plant cover was positively correlated with altitude, boulder, fine sand and $\mathrm{Fe}(\mathrm{r}=0.129,0.119$, 0.171 and 0.305 respectively), while negatively correlated with gravel and coarse sand $(r=-0.127$ and 0.113). In addition, species richness was positively correlated with altitude, stones, boulders, gravel, silt \& clay and $\mathrm{Fe}(\mathrm{r}=0.478,0.166,0.318,0.158,0.568$ and 0.307 respectively) while negatively correlated with other variables. Likewise, species diversity (Shannon index) was positively correlated with altitude, stones, boulders, gravel, silt \& clay moisture content and Fe ( $\mathrm{r}$ $=0.461,0.208,0.313,0.162,0.365,0.185$ and 0.326 respectively), while negative correlated with other variables. While, species diversity (Margalef index) were Positively correlated with silt \& clay and $\mathrm{Fe}(\mathrm{r}=0.819$ and 0.327 , respectively), while negatively correlated with other variables.

\section{Discussion and conclusion}

Sinai Peninsula in Egypt is a very important and unique spot as a junction between Africa and Asia. It is characterized with very high plant diversity of which $80 \%$ are found in South Sinai. Endemism is grand among many species in the area as well as rare and threatened species (Moustafa and Klopatek 1995; Ayyad et al., 2000).

The target of the present study is to provide an overview of species diversity in different landforms and edaphic conditions of twenty-two Wadis of South Sinai. The vegetation survey resulted in one hundred and sixty four plant species which belong to forty three families. The families Compositae, Labiatae, Graminae and Leguminosae contained the majority of species, while the remaining twenty two families were only represented by one species each.

Six life-forms were recognized in this area. Chamaephytes, therophytes, hemicryptophytes, perennial grasses, phanerophytes, and geophytes, with the former being the most dominant followed by therophytes and hemicryphytes. Life-form distribution of desert plants is very closely correlated with topography, landform and rainfall (Kasses \& Girgis, 1965; Zohary, 1972; Orshan, 1986 and Danin \& Orshan, 1990). For instance, chamaephytes dominate slopes; foothills and wadi bed systems whereas therophytes prefer to grow in soil pockets and sandy wadis (Moustafa \& Kamel 1995). Meanwhile, three principal life-forms were found to inhabit gorge habitats in the study area where there is an availability of water (Moustafa \& Zaghloul 1993; Moustafa \& Kamel, 1995 and Zaghloul, 1997). Distribution of vegetation depends mainly on tempera-ture and moisture, while, elevation, land-form type, nature of soil surface deposits and soil texture are factors affecting the gradient of moisture and tempera-ture (Ayyad \& Dix, 1964; Whittaker, 1975; Moustafa, 1990 and Zaghloul, 1997).

As a consequence we can find that, the communities II, III and VII were the highest in species richness and diversity whereas; in community II that occurred in W. Gragnia, W. Arbaeen and W. Telah, the wadis represented high altitude, very diverse land-forms and soil types, while the land-forms complexity ranged between wadi beds, slopes and terraces of various soil types, for instance alluvial plains and volcanic soils ensure high soil fertility while the course sand and granite boulders act as water reservoirs. All these parameters lead to the formation of different micro habitats for diverse species to live. 
Second, community III, beside the elevated species diversity, it had the highest mean value of individuals number; this community was found in wadis at the highest altitudes named wadi Hamata and W. Talaa at1400-1700m a.s.l. where high moisture and low temperature levels ensure suitable conditions for optimum growth, plus the two wadis were characterized mainly by alluvial soil in wadi beds and granite slope formations. The higher number of individuals is probably due to suitable temperature levels and less human impact as such elevated altitudes can act as a natural barrier that protects the plants from overgrazing and over-collection.

On the contrary, although it has high species diversity, community VII had the lowest mean value of individual numbers, as it was found in wadis of vast wadi beds such as Wadi El-sheikh and wadi El-Raha which are considered an important center for local communities to inhabit, exposing consequently, the different plant species to heavy grazing, over-collection and other human related stresses specially the dominant species of the community the Acacia tortilis, a critically endangered tree for being the locals favorite species as firewood (Zaghloul et al., 2007) .

On the other hand, lowest species diversity and richness was recorded at community $\mathrm{V}$, which is located at wadi Solaf at low altitude which indicates low moisture and high temperature, as well as, in Wadi Elsheikh, the community thrives under the various stresses of human impact.

Finally we may conclude that, in arid environments such as South Sinai, temperature and water availability are the main factors controlling species distribution which in our study is governed by altitudes. However, keen conservation plans should be sat up to overcome the different anthropogenic stresses as well as monitoring the changes in the dynamics of different plant communities in response to changing climate in the region.

\section{References}

ALLAN, S. E., H. M. GRIMSHAW., AND J. A. Parkinson. (1976). Chemical Analysis. In: Chapman, S. B. (ed.): Methods in Plant Ecology. Blackwell Scientific Publications. pp. 411-466.

AYYAD, M. A., AND, R. L. Dix. (1964). An analysis of vegetation micro environmental complex on prairie slopes in Saskatchwan. Ecological Monographs, 34: 421-442.

AYYAD, M.A., A.M. FAKHRY., A.R.A. MOUSTAFA. (2000). Plant biodiversity in the St. Catherine area of the Sinai peninsula, Egypt. Biodivers. Conserv. 9: 265-281.

BARBOUR, M. G., J. H . BURK., AND W. D. PITTS. (1987). Terrestrial plant ecology. Second edition. The benjaamin/ CummingsPublishing Company, Inc. 634.

BOULOS, L. (1982). Flora of Sinai. In: Environment in Sinai. Arab Office of Youth and Environment, AlAhram, Cairo, p.45-58 (Arabic).
BOULOS, L., (1995). Flora of Egypt, Checklist. $1^{\text {st }}$ Edn., Al-Hadara Publishing, Cairo, Egypt, Pages: 283.

DANIN, A. (1983). Desert vegetation of Israel and Sinai Jerusalem: Cana Publishing House.

DANIN, A., AND G. ORSHAN. (1990). The distribution of Raunkiaer life forms in Isreal in relation to the environment. J. Vegetation Sci., 1: 41-48.

HAUSENBUILLER, R. L. (1985). Soil Science and Principles Practices. 3 eds., Wm c. Brown Company Publishers, $610 \mathrm{pp}$.

HAMMAD, F. A. (1980). Geomorphologic and Hydrogeological aspects of Sinai Peninsula, A.R.E. Annals of the Geological Survey of Egypt. Vol. X, 807-817.

KASSAS, M., AND GIRGIS, W. A. (1965). Habitat and plant communities in the Egyptian desert. V I. The Units of desert ecosystem. J. Ecology, 53: 715728.

KASSEM, M. (1981). Hydrogeological Studies in Wadi Feiran, South Western Sinai. M.Sc. Thesis, Geol. Dept., Suez Canal Uni., Ismailia, Egypt, pp 181.

MOUSTAFA, A. A. (1990). Environmental Gradients and Species Distribution on Sinai Mountains. Ph.D. Thesis, Botany Department. Faculty of Science, Suez Canal University, Egypt, 115 pp.

MOUSTAFA, A. A., W. M. KAMAL. (1995). Ecological notes on the floristic comosition and endemic species of Saint Catherine area, South Sinai, Egypt. Egyptian Journal of Botany 35(2): 177-200.

MOUSTAFA, A. A., J. M. KLOPATEK. (1995). Vegetation and landforms of the Saint Catherine area, southern Sinai, Egypt. Journal of Arid Environments, 30: 385-395.

MOUSTAFA, A. A., M. S. ZAGHLOUL. (1993). Environmental factors affecting the distribution of plant species in gorge habitats, South Sinai, Egypt. Proc. $1^{\text {st }}$ Conf. Egypt. Hung. Env. Egypt, 268-274.

MOUSTAFA, A. A., M. S. ZAGHLOUL. (1996). Enivronment and vegetation in the montane Saint Catherine area, south Sinai, Egypt. J. Arid Environments 34: 331-349.

ORSHAN, G. (1986). The desert of Middle East. In: Evenari, M., Noy-Meir, I., and Goodall, D. W. (eds.): Ecosystems of the world, 12 B, Hot deserts and arid shrub lands. Elsevier, Amsterdam. 1-28 pp.

SAID, R. (1962). The geology of Egypt. Elsevier, Publ., Amsterdam. 377 pp.

SAID, R. (1990). The geology of Egypt. Elsevier, Publ., Amsterdam. 734 pp.

SHABANA, M. A. (1988). Phytosociological study of the Wadis of Catherine area (South Sinai). M.Sc. Thesis. Botany Department, Faculty of Science, Suez Canal University, Ismailia, Egypt. 121 pp.

TACKHOLM, V. (1974). Students' Flora of Egypt. $2^{\text {nd }}$ edition, Beirut: Cairo University, Egypt. 888 pp.

WHITTAKER, R. H., W.A.NIERING. (1975).Vegetation of the Santa Catalina Mountains, Arizona. V. Biomass, production, and Diversity along the elevation gradient. Ecological study of 
America, 56(4): 771:790.

WILDE, S. A., G. K. Voigt, AND J. G. LYER. (1972). Soil and Plant analysis for tree culture. Edited by Gordon Chesters, Applied Science Publisher. 172pp.

ZAGHLOUL, M. S. (1997). Ecological studies on some ndemic plant species in south Sinai, Egypt. M.Sc. Thesis. Botany Department, Faculty of Science. Suez canal University, Ismailia, Egypt.279 pp.
ZAGHLOUL, M. S., J. L. HAMRICK.., AND MOUSTAFA, A. A. (2007). Conservation of Acacia ortillas subsp. Raddiana populations in Southern Sinai, Egypt. I- Genetic diversity and structure. Catrina. 2(1): 51-60.

ZOHARY, M. (1972). Flora Palestine Part 2: The Israel Academy of Sciences and Humanities, Jerusalem.

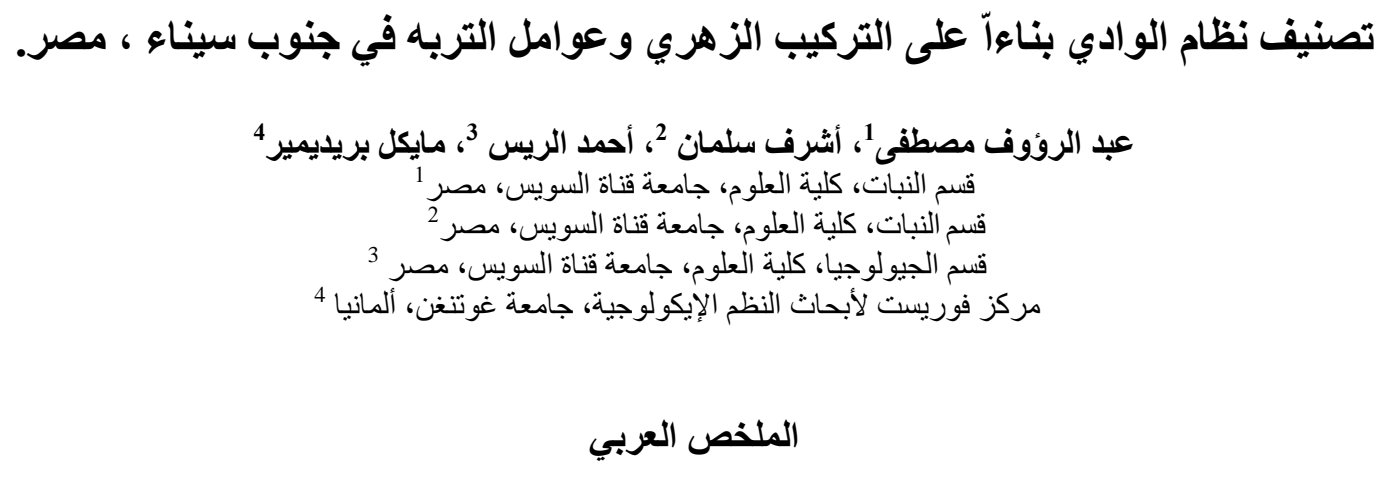

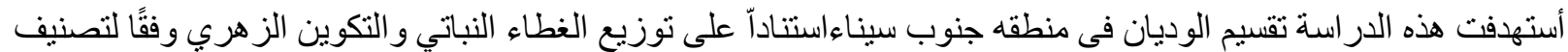

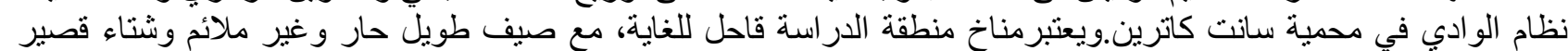

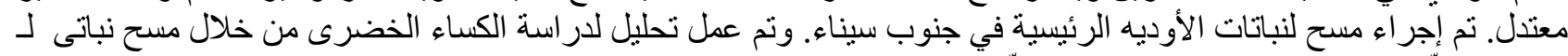

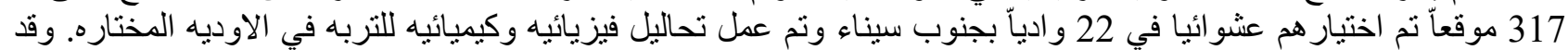

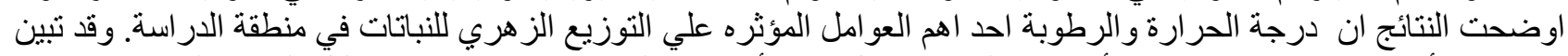

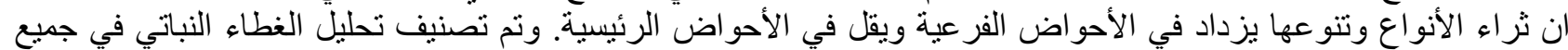
الوديان إلى أربع مجموعات: المجموعة (أ) تشمل منطقة الحوض الرئيسيس

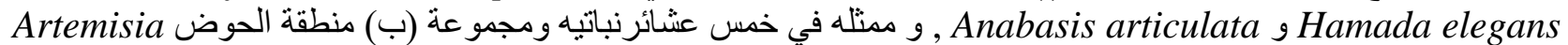
ونdaica

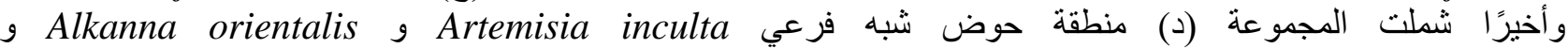
. Artemisia Judaica 